Pobrane z czasopisma Annales H - Oeconomia http://oeconomia.annales.umcs.pl Data: 26/04/2023 12:15:04

DOI:10.17951/h.2017.51.3.39

\begin{tabular}{lcl}
\hline \multicolumn{1}{c}{ A N N A L E S } \\
UNIVERSITATIS MARIAE CURIE-SKŁODOWSKA \\
LUBLIN - POLONIA \\
VOL. LI, 3 & SECTIO H \\
\hline
\end{tabular}

Maria Curie-Skłodowska University in Lublin, Faculty of Economics

MONIKA JAKUBIAK

monika.jakubiak@umcs.pl

\title{
Employers' Expectations Regarding Competences of Graduates of Economics
}

Oczekiwania pracodawców wobec kompetencji absolwentów kierunków ekonomicznych

Keywords: employers' expectations; graduates' competences; graduates of economics

Słowa kluczowe: oczekiwania pracodawców; kompetencje absolwentów; absolwenci kierunków ekonomicznych

JEL code: M12; M51; M54

\section{Introduction}

Modern economy requires graduates to possess particular competences, not only those associated with knowledge and skills emerging from the particular course of studies. University studies constitute a period when young adults shape foundations of their prospective careers. In the times of turbulent changes on labor market, the young are expected to exhibit specific competences, especially activity, flexibility, openness to change, and skills enabling them to cope in the ever-changing reality.

The subject matter of the present paper contributes to the discussion on shaping university graduates' vocational competences. The literature of the subject highlights the need for attitudes and competences of graduates to be molded, in the framework of university curricula among others [Targalski 2003]. 


\section{Competence requirements in literature}

Modern organizations operate in the state of constant flux. The situation is determined primarily by globalization, development of technologies, employees' mobility, products', and even companies', shortening life cycle. When companies themselves, and their surrounding environment as well, undergo constant changes, intangible assets gain considerable significance. In globalization and innovation, people emerge as the most critical capital of organizations. It is employees' competences, their skills, potential, and creativity that constitute a source of competitive advantage. As a result of one type of competences becoming outdated, and another set emerging, employee competences may offer a permanent competitive advantage [Kramer 2011; Crook et al. 2011]. As a consequence, the development of a committed, loyal team has become a significant challenge for organizations. It results from e.g. greater diversity of teams, and the necessity of adopting a specific approach towards management of such conglomerates [Rudolph and Zacher 2015].

The literature of the subject offers several definitions and understandings of the term "competences". The term refers to numerous players - organizations, employees, managers, graduates. Competences have become an interest for experts in several fields - management, sociology, pedagogy, psychology. Such a broad attention attracted by the issue of competences results in the lack of agreement with regard to the definition of the term. In addition, the literature of the subject features numerous terms used interchangeably, e.g. "skills", "abilities", and even "qualifications" [Sajkiewicz 2002, p. 90; Pocztowski 2008, pp. 96-97; Shavelson 2010; Hartig et al. 2008; Baran and Kłos 2014; Sitko-Lutek 2015; Rakowska and Cichorzewska 2016].

Due to the subject matter of the present paper, a premise was made that competences constitute "a combination of knowledge and skills reflecting both tacit knowledge and skills required to conduct specific tasks" [as defined by Sitko-Lutek and Łoboda 2007, p. 18].

Research issues of the present paper pertain to graduates' competences. Indicating an additional approach to understanding vocational competences, resulting from the implementation of the Bologna Process, seems significant. Qualifications are understood in terms of learning outcomes. As a consequence, they are granted to people who achieved certain outcomes in the process of learning [Chmielecka 2010, p. 6].

At present, universities specify the profile of a graduate of their courses. In accordance with guidelines of the Bologna Process and regulations of the National Qualifications Framework, a precise definition of the profile requires not only knowledge acquired in the course of studies to be determined, but also skills (including practical ones) and social competences to be established.

The issue of graduates' profiles has been discussed in numerous studies conducted among employers, students and graduates. In the project implemented by the Polish Agency for Enterprise Development titled Bilans Kapitału Ludzkiego 
[Review of Human Capital], several competence gaps regarding vocational profiles of Polish university graduates were identified [Górniak 2015]. According to results of the project, requirements regarding modern graduates of universities are growing. People are required to possess not only expert knowledge and vocational skills, but also qualifications going beyond these skills [Chmielecka 2008].

Discrepancies between graduates' qualifications and employers' requirements may be based on numerous factors. Primarily, young adults who decide upon a particular field of studies do not associate it with the selection of a particular prospective profession. In addition, opportunities for developing the required skills in the course of studies are not always present due to the fact that, frequently, these are over-theoretical and detached from realities of economy [Werner 2011, p. 116]. Such a phenomenon poses new challenges for university studies, which ought to supply knowledge, but also teach students how to apply it in practice, and how to efficiently and effectively develop competences [Orczykowska 2006, pp. 54-55]. Modern education ought to focus on transferring skills enabling independent actions to be taken and developing self-organization and active adaptation to changing realities [Okoń-Horodyńska 2008; Cieślik et al. 2011].

When considering graduates' competences, recent changes encompassing the perception and the course of careers, ought to be discussed [Sikorski 2008, p. 54]. As a result of dynamically changing conditions, growing competitiveness, and internal changes, modern organizations are frequently unable to offer their employees a steady course of career and employment. As a consequence, careers of many are characterized with new dynamics and discontinuity of professional experience, which make these increasingly less predictable [Verbruggen 2010]. Researchers dealing with this new model of career highlight that people who desire to pursue their career globally, in ever-changing labor market, must take responsibility over their careers into their own hands [Briscoe and Hall 2006; Plomp et al. 2016].

Factors determining the position of an individual on modern labor market include: the application of educational potential, quality of education and training, the structure of professional activity, employees' knowledge and skills, both hard, associated with the profession, and soft ones connected with predispositions for teamwork. The latter group has become the object of particular interest on the part of employers [Sztanderska and Wojciechowski 2008, p. 59].

\section{Methodology}

The subject matter of the present paper pertains to employers' expectations towards job applicants. Particular attention was devoted to expectations regarding graduates entering labor market upon completing university studies in finance and accounting, which belong to the social, and economics, field (in accordance with the classification of the Central Statistical Office of Poland). 
Empirical data was collected by means of a diagnostic poll with the use of an interview. Data was compiled in 2016 in Lublin, among companies employing graduates of studies of economics. The study was realized in the framework of a project implemented at the Faculty of Economics (Maria Curie-Skłodowska University).

The questionnaire consisted of several questions encompassing recruitment and selection of graduates of economics. HR departments of the analyzed organizations were interviewed.

The objective of the study was to identify expectations of employers who employ graduates of finance and accounting studies with regard to their fitness for employment. The analysis encompassed required competences and areas defined by employers as additional qualifications. The analysis examined expectations regarding knowledge, skills and social competences in particular.

Studies were conducted in 2016 among 28 organizations whose HQ or branches are located in Lublin and employ graduates of economics. Figure 1 presents types of examined organizations. The largest group of respondents consisted of financial institutions, including banks (29\%). Every fourth organization offered consulting or advisory services. Accounting offices and insurance agencies (14\%), BPO/SSCs (business process outsourcing and service sharing centers, respectively) were slightly less represented.



Figure 1. Structure of examined companies indicating type of business activity $(\%, \mathrm{n}=28)$

Source: Author's own study.

\section{Competences of finance and accounting graduates in light of employers' expectations}

The subject matter of the present paper pertains to employers' expectations towards competences of finance and accounting graduates. The identification of positions recruitment in the organizations was conducted for constituted the first research aspect. 


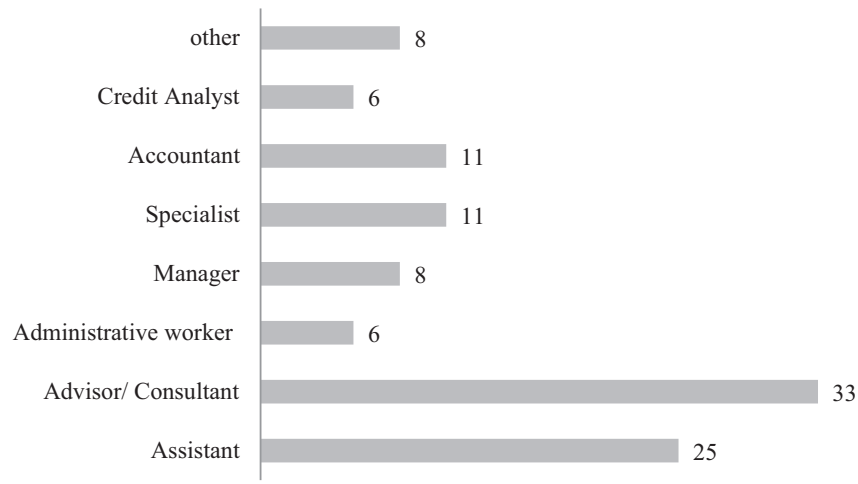

Figure 2. Positions the examined organizations recruited for $(\%, n=39)$

Source: Author's own study.

In the assessed period, the examined organizations recruited advisors or consultants, which was valid for every third vacancy. Customer advisors to work in consulting or finance institutions (e.g. banks) were sought after the most. Every fourth position was open to assistants. Accountants and specialists (11\% of the total number of job offers) and managers (8\%) were recruited slightly less frequently. As far as administrative jobs are concerned (6\%), vacancies were available only in local government institutions.

The analysis of results indicates that smaller enterprises conducted a single recruitment process to fill one vacancy at a given time. On the other hand, examined corporations recruited for numerous positions open in various branches in Poland at a given time.

Employers' expectations towards prospective employees' competences constituted the next thematic area assessed in the study. The majority of organizations divide these into two groups, i.e. crucial (obligatory), and desirable requirements. Applicants who do not possess competences belonging to the former group are not usually considered for the position. These competences are primarily verified at the initial stage of recruitment, i.e. in the analysis of applications ( $\mathrm{CV}$ and cover letter). The situation is different for applicants who do not possess desirable competences. Their applications may be considered in case when remaining candidates do not possess these as well.

In accordance with guidelines of the National Qualifications Framework for higher education, employers' expectations regarding graduates' competences were divided into three areas, i.e. knowledge, skills, and social competences (including personal predispositions) (Table 1).

As far as knowledge is concerned, employers primarily expect a university diploma (they were willing to accept candidates who would complete their higher education while being employed), specialized knowledge associated with the field of studies (finances, law, economy, management, etc.), and familiarity with legal regulations necessary to complete work tasks. 
Pobrane z czasopisma Annales H - Oeconomia http://oeconomia.annales.umcs.pl Data: 26/04/2023 12:15:04

MONIKA JAKUBIAK

Table 1. Obligatory expectations regarding competences of graduates

\begin{tabular}{|c|c|}
\hline \multirow{3}{*}{ Knowledge } & higher education \\
\hline & knowledge related to the field of studies \\
\hline & familiarity with regulations \\
\hline \multirow{6}{*}{ Skills } & operation of office equipment \\
\hline & \begin{tabular}{|l|} 
MS Office skills (including Excel) \\
\end{tabular} \\
\hline & at least communicative English skills \\
\hline & decision-making \\
\hline & vocational skills associated with work duties \\
\hline & analytical thinking \\
\hline \multirow{9}{*}{ Social competences } & flexibility \\
\hline & independence and autonomy \\
\hline & preciseness \\
\hline & commitment to work tasks \\
\hline & excellent work management \\
\hline & ability to work to deadlines \\
\hline & orderliness \\
\hline & willingness to develop qualifications \\
\hline & teamwork \\
\hline
\end{tabular}

Source: Author's own study.

Expectations regarding skills are much broader. Vocational skills associated with duties at work, technical skills (computer and software literacy, team work), and English communicative skills were highlighted.

With regard to social competences, interpersonal skills (communication, establishing relations, team work), and predispositions such as independence, precision, time management, ability to work to deadlines, and willingness to improve competences, were emphasized.

Employers were also queried about expectations pertaining to candidates' experience. The majority of respondents observed they search for those who have completed at least vocational internship in a similar position.

Desirable competences constituted a separate category of examined expectations. Most frequently, these encompassed professional education, work experience in a similar position, additional professional trainings, work skills associated with job description (e.g. familiarity with accounting software, regulations for accounting and bookkeeping, tax law, etc.). Additional skills also encompassed foreign language skills (e.g. German) and C1-level foreign language skills.

The higher the position, the greater expectations with regard to applicants' competences were observed. As far as education is concerned, in case of lower-level positions, any diploma of higher education was accepted. However, applicants for managers' positions (even lower level managers) ought to possess a university diploma, preferably in economics (finances and accounting).

In case of independent positions (specialists, managers), expectations regarding skills have also grown. Due to a broader scope of duties, including management and 
supervision of subordinates, applicants are expected to possess well-developed skills in management of their own and team's work, planning, and monitoring progress towards objectives.

\section{Discussion and practical recommendations}

The subject matter of the present paper pertained to competences of economics graduates in light of employers' expectations. The analysis of results indicated the need for employees with finance and accounting background.

The majority of enterprises employing graduates operate in financial, consulting and outsourcing services. Results of studies were confirmed in HAYS reports [Raport ptacowy... 2016]. According to these, professions encompassing consulting both for individual clients and institutions, will gain significance in the near future.

Fresh graduates are offered lower level positions e.g. assistants or junior consultants. In this case, employers' expectations are not very high with regard to education and professional experience. In case of specialists and managers' positions expectations are higher. Frequently, they pertain to skills of putting theoretical knowledge into practice, application of computer software, and previous experience in similar positions.

Globalization and changes in organizations and their surroundings result in a growing need for qualified employees who possess both suitable experience and knowledge, but also skills enabling these to be applied in practice. Results of the study confirm observations made in literature, which acknowledge a growing demand for the so-called soft competences, such as interpersonal skills, team work, communicative skills, flexibility, leadership, fostering development [Van Dalen et al. 2010]. According to employers, it is interpersonal skills that have begun to constitute employees' significant attributes which may determine an individual's employment. The literature of the subject highlights that social competences (including interpersonal ones) facilitate success both in private and professional life [Heckman and Kautz 2012; Walumbwa and Hartnell 2011].

Results of studies confirm that expectations towards applicants are also determined by the size and type of organization. Large businesses, especially international corporations, recruit people proficient in English and with communicative level of another foreign language. On the other hand, even for entry-level positions, local government institutions expect familiarity with legal regulations in the field the institutions operate in.

The analysis of results of the study enables the following recommendations for students of economics to be formulated:

1. Students ought to be aware that the period of studies should be considered as an investment in a prospective career. Therefore, monitoring information on potential employers' expectations seems worthwhile. As a result, while 
studying, students will be able to undertake actions boosting employment opportunities for positions fitting their qualifications. This is especially true for developing practical skills, learning foreign languages, and operation of computer software, etc.

2. When searching for factors facilitating employability, the literature of the subject indicates a significant role of activities undertaken by students during their studies, becoming familiar with realities of work in a particular profession in the course of internships or voluntary work. This is vital in light of the demand for people possessing experience in similar positions, which was verified in the present study.

3. Activity in the course of studies, e.g. membership in science clubs, student government, or extramural departments, facilitated the development of interpersonal skills. Employers voiced the demand for skills in the area of team work, making and maintaining relations, commitment, orderliness, time management, etc.

4. Students ought to be aware that upon graduating and entering labor market they ought to self-develop, improve qualifications, and participate in trainings. Respondents indicated that young people should manifest willingness to learn and develop competences.

The author of the study is aware that the paper does not exhaust the issue. It constitutes a contribution to the discussion regarding employers' expectations towards work applicants. In the future, a broader study encompassing a greater number of enterprises is worth-making. The study would examine factors determining employment but also those enabling individuals to remain on labor market.

\section{Bibliography}

Baran, M., Kłos, M., Competency Models and the Generational Diversity of a Company Workforce, "Economics \& Sociology” 2014, vol. 7, no. 2, pp. 209-220.

Briscoe, J.P., Hall, D.T., The Interplay of Boundaryless and Protean Careers: Combinations and Implications, “Journal of Vocational Behavior" 2006, vol. 69, no. 1, pp. 4-18.

Chmielecka, E. (ed.), Od Europejskich do Polskich Ram Kwalifikacji. Model Polskich Ram Kwalifikacji, Ministerstwo Edukacji Narodowej, Warszawa 2010.

Chmielecka, E., Edukacja dla społeczeństwa mądrości, 2008, available at: www.e-edukacja.net/czwarta/ referaty [access: 10.07.2016].

Cieślik, J., Matusiak, K.B., Guliński, J., Skala-Poźniak, A., Edukacja dla przedsiębiorczości akademickiej, Polska Agencja Rozwoju Przedsiębiorczości, Poznań-Warszawa 2011.

Crook, T.R., Todd, S.Y., Combs, J.G., Woehr, D.J., Ketchen, Jr D.J., Does Human Capital Matter? A Meta-Analysis of the Relationship Between Human Capital and Firm Performance, "Journal of Applied Psychology" 2011, vol. 96, no. 3, pp. 443-456.

Górniak, J. (ed.), Polski rynek pracy - wyzwania i kierunki działań, Polska Agencja Rozwoju Przedsiębiorczości, Warszawa-Kraków 2015. 
Hartig, J., Klieme, E., Leutner, D. (eds.), Assessment of Competencies in Educational Contexts: State of the Art and Future Prospects, Hogrefe \& Huber, Göttingen 2008.

Heckman, J.J., Kautz, T., Hard Evidence on Soft Skills, “Labour Economics” 2012, vol. 19, no. 4, pp. $451-464$. http://ec.europa.eu/education/lifelong-learning-policy/eqf_en.htm [access: 11.07.2016].

Kramer, M.R., Creating Shared Value, "Harvard Business Review" 2011, vol. 89, no. (1/2), pp. 62-77.

Łoboda, M., Sitko-Lutek, A., Kompetencje i luka kompetencyjna organizacji, [in:] A. Sitko-Lutek (ed.), Polskie firmy wobec globalizacji. Luka kompetencyjna, Wydawnictwo Naukowe PWN, Warszawa 2007.

Okoń-Horodyńska, E., Education for Innovation. Are Only the Selected Few Bound for Success in Innovation?, "Science and Higher Education" 2008, no. 1, pp. 34-54.

Orczykowska, A., Szkolnictwo wyższe a wymagania rynku pracy, "Nauka i Szkolnictwo Wyższe" 2006, no. 2/28/, pp. 49-64.

Plomp, J., Tims, M., Akkermans, J., Khapova, S.N., Jansen, P.G.W., Bakker, A.B., Career Competencies and Job Crafting: How Proactive Employees Influence Their Well-Being, "Career Development International" 2016, vol. 21, no. 6, pp. 587-602.

Pocztowski, A. Zarzadzanie zasobami ludzkimi. Strategie - Procesy-Metody, Polskie Wydawnictwo Ekonomiczne, Warszawa 2008.

Rakowska, A., Cichorzewska, M., Competences Needed on the Future Labour Market-Results from Delphi Method, Managing Innovation and Diversity in Knowledge Society Through Turbulent Time: Proceedings of the MakeLearn and TIIM Joint International Conference 2016, ToKnowPress, 2016, pp. 869-872.

Raport płacowy 2016. Trendy na rynku pracy, HAYS, 2016.

Rudolph, C.W., Zacher, H., Intergenerational Perceptions and Conflicts in Multi-Age and Multigenerational Work Environments, [in:] L.M. Finkelstein, D.M. Truxillo, F. Fraccaroli, R. Kanfer (eds.), Facing the Challenges of a Multi-Age Workforce: A Use-Inspired Approach, Routledge, New York 2015, pp. 253-282.

Sajkiewicz, A., Jakość zasobów pracy, Poltext, Warszawa 2002.

Shavelson R.J., On the Measurement of Competency, "Empirical Research in Vocational Education and Training" 2010, vol. 2, no. 1, pp. 41-63.

Sikorski, Cz., Typy i dylematy kariery zawodowej, "Organizacja i Zarządzanie” 2008, no. 1.

Sitko-Lutek, A., Kompetencje menedżerskie w kontekście innowacyjności przedsiębiorstw, “Annales Universitatis Mariae Curie-Skłodowska, Sectio H - Oeconomia” 2015, vol. 47, no. 1, pp. 141-148.

Sztanderska, U., Wojciechowski, W., Czego (nie) ucza polskie szkoty? System edukacji a potrzeby rynku pracy w Polsce, Fundacja Forum Obywatelskiego Rozwoju, Fundacja im. Friedricha Eberta, Warszawa 2008.

Targalski, J., University Education for Entrepreneurship: Assumptions and Results, "Cracov University of Economics Research Bulletin” 2003, no. 622, pp. 21-28.

Van Dalen, H. P., Henkens, K., Schippers, J., Productivity of Older Workers: Perceptions of Employers and Employees, "Population and Development Review", 2010, 36, pp. 309-330.

Verbruggen, M., Career Counseling in the New Career Era, "Review of Business and Economics" 2010, vol. LV, no. 1, pp. 2-22.

Walumbwa, F.O., Hartnell, C.A., Understanding Transformational Leadership-Employee Performance Links: The Role of Relational Identification and Self $\square$ Efficacy, "Journal of Occupational and Organizational Psychology" 2011, vol. 84, no. 1, pp. 153-172.

Werner, E., Absolwent szkoły wyższej - sylwetka w kontekście społecznym, "Nauka i Szkolnictwo Wyższe" 2011, no. 1/37, pp. 106-111.

\section{Employers' Expectations Regarding Competences of Graduates of Economics}

Modern economy requires graduates to possess particular competences, not only those associated with knowledge and skills emerging from the particular course of studies. The subject matter of the present paper contributes to the discussion on shaping university graduates' vocational competences. The objective of the study was to identify expectations of employers who employ graduates of finance and accounting studies 
with regard to their fitness for employment. The analysis encompassed required competences and areas defined by employers as additional qualifications. As the results of the study, the practical recommendations for students of economics were formulated.

\section{Oczekiwania pracodawców wobec kompetencji absolwentów kierunków ekonomicznych}

Współczesna gospodarka oczekuje od absolwentów szczególnych kompetencji związanych nie tylko z wiedzą i umiejętnościami wynikającymi z ukończenia danego kierunku studiów. Problematyka prezentowanego opracowania wpisuje się w dyskusję nad kształtowaniem kompetencji zawodowych absolwentów szkół wyższych. Celem badań była identyfikacja oczekiwań pracodawców zatrudniających absolwentów kierunku finanse i rachunkowość wobec kandydatów do pracy. Analizie poddano wymagane kompetencje oraz te obszary, które pracodawcy oceniali jako dodatkowe kwalifikacje. Dzięki przeprowadzonym badaniom opracowano rekomendacje praktyczne dla studentów kierunków ekonomicznych w zakresie zapotrzebowania pracodawców na kompetencje absolwentów. 